\title{
The Effect of Employee Benefit Liabilities, Sales Growth, Capital Intensity, and Earning Management on Tax Avoidance
}

\author{
Andri Marfiana ${ }^{a}$, Yohanes Praka Mael Putra ${ }^{b}$ \\ aPoliteknik Keuangan Negara STAN, andri.marfiana@pknstan.ac.id \\ bPoliteknik Keuangan Negara STAN, yohanespraka@gmail.com
}

\begin{abstract}
A b s t r a c t
Tax avoidance is a strategy that is common in tax management. As part of management strategy, tax avoidance is important to know for a manager. The purpose of this research is to examine the level of tax avoidance of the manufacturing industry in Indonesia and the role of employee benefit liabilities, sales growth, capital intensity, and earnings management in effecting this. This study uses purposive sampling and 78 manufacturing companies listed on Indonesia Stock Exchange (IDX) from 2016 to 2019 that were selected as research samples and obtained a final sample of 312 firm-years observation. The result of panel data regression using a random effect model finds strong evidence that employee benefit liabilities have a negative effect on tax avoidance while sales growth, capital intensity, and earning management has a positive effect on tax avoidance.
\end{abstract}

Keywords: Employee benefit liabilities, sales growth, capital intensity, earning management, tax avoidance.

\begin{abstract}
A b s t r a k
Penghindaran pajak adalah salah satu strategi yang biasa digunakan dalam manajemen pajak. Sebagai bagian dari manajemen strategi, maka penghindaran pajak penting diketahui oleh seorang manajer. Tujuan dari penelitian ini adalah untuk menguji tingkat penghindaran pajak industri manufaktur di Indonesia dan peran kewajiban imbalan kerja, pertumbuhan penjualan, intensitas modal, dan manajemen laba dalam mempengaruhi hal tersebut. Penelitian ini menggunakan purposive sampling dan 78 perusahaan manufaktur yang terdaftar di Bursa Efek Indonesia (BEI) dari tahun 2016 hingga 2019, yang dipilih sebagai sampel penelitian dan diperoleh sampel akhir sebanyak 312 data panel perusahaan. Hasil regresi data panel dengan menggunakan model random effect menemukan bukti kuat bahwa kewajiban imbalan kerja berpengaruh negatif terhadap penghindaran pajak sedangkan pertumbuhan penjualan, intensitas modal, dan manajemen laba berpengaruh positif terhadap penghindaran pajak.
\end{abstract}

Kata Kunci: Imbalan pasca kerja, pertumbuhan penjualan, besaran modal, manajemen laba, penghindaran pajak.

\section{Introduction}

Taxes are pulse to build the country as a revenue that is used for building Indonesia's economy. By doing responsibility to pay and to report income means citizens are participating not only in financing but also in developing the country. In 2020, in the middle of the government's effort to increase awareness to pay taxes, people were surprised by the Corona Virus outbreak (van Dorp et al., 2020). As a result, Indonesia was affected by this virus either (Marfiana, 2020). Indonesia officially declared a recession because the Gross Domestic Product (GDP) of Indonesia was minus 3.49 percent in the third quarter of 2020 (Aprilianti, 2021). Let alone recession, even in the normal condition, tax revenues have not yet been able to fulfill the target of the 
Government Revenue and Expenditure Budget. By looking at the Central Government Financial Report, it is known that the tax target has not been achieved in the last 10 years. The highest tax revenue against the tax target was achieved at $99.45 \%$ in 2011 . The lowest tax revenue against the tax target was achieved at $83.3 \%$ in 2015 . For this reason, research is needed to encourage tax revenue in accordance with predetermined targets.

Manufacturing sector is one of the main contributors to tax revenue. In 2019, the manufacturing sector contributed 29,4\% of tax revenue or about Rp365,39 trillion. Manufacturing sector is also supporting Indonesia's economy because it contributed $20.21 \%$ of total Gross Domestic Product in 2019. However, based on the Performance Report of the Ministry of Industry, the processing industry has decreased its contribution to GDP since 2015 by $21 \%, 2016$ by $20.5 \%, 2017$ by $20.16 \%$, and in 2018 by $19.86 \%$. In 2019, after conducting an economic impact evaluation, the Ministry of Industry supports the improvement of the performance of five manufacturing sectors (Kemenperin, 2020). With support of industrial technology 4.0, it is hoped that it can not only reduce operational costs but also increase productivity efficiently. For this reason, research is needed on the manufacturing sector because the expected contribution is large to GDP and can increase the profit of each company so the tax authorities can maximize tax potential for state revenues. The increase of the profit can be observed through the growth sales and capital intensity owned by the company to do their operations.

An increase in profit provides a trade-off that if the profit is large, the tax burden is also large (Wind et al., 2020). Increased earnings allow managers to do earnings management. Earnings management is a process for manipulating financial statements with certain objectives so that organizations get benefit from these manipulations (Shayan-nia et al., 2017). In Indonesia, earnings management has been done by Garuda Indonesia. Audit results conducted by Financial Services Authority (OJK), BPK and Indonesia Stock Exchange (BEI) stated that Garuda Indonesia recognized income simultaneously in one year as an earnings management measure (Pablo, 2019; Azzura, 2019).

Furthermore, the issuance of the Omnibus Law brings out several dilemmas. First, PP No. 30 of 2020 regulates gradual reduction of corporate income tax rates from $25 \%$ to $22 \%$ for $2020-2021$ and in 2022 to $20 \%$. The effect of this tariff reduction is that Indonesia has a possibility to get a loss of tax revenue. Suryo Utomo, Director General of Taxes, said that the calculation of the potential loss of revenue affected by the gradual reduction in income tax is around Rp80 trillion (Victoria, 2020). This is reinforced by research which says whatever the tax rate imposed by the government, there will still be a company effort to use tax deductible expenses to reduce its tax expense as a form of tax avoidance (Oktariani \& Lembut 2019). For this reason, the government must anticipate tax avoidance as preparation to avoid another loss of tax revenue. Tax avoidance is an act of avoiding legal taxes by exploiting tax law loopholes and using arguments without violating tax laws (Dyreng et al., 2014). Several practices and factors that can influence tax avoidance are previously described such as leverage (Noor et al., 2015), financial leverage and capital intensity (Stickney \& McGee, 1982), sales growth 
(Swingly \& Sukartha, 2015), earnings management (Erickson et al., 2004; Frank et al., 2009). Current Effective Tax Rate (ETR) is the current tax expense which is often used as a proxy for tax avoidance. In this study, the Current Effective Tax Rate (ETR) is used to measure tax avoidance from Hanlon \& Heitzman (2010) who said that this measurement provides a possible impact on accounting measurements, reflect deferral strategies, reflect inappropriate avoidance, and can be calculated under respective jurisdictions.

UU Cipta Kerja as a part of Omnibus Law also became a polemic. One of the reasons is decreasing benefit in severance pay which is part of the internal employee benefits in Act No.13 of 2003 article 167. UU Cipta Kerja removes article 167. Workers were worried about this. They said that there will be opportunities for employers not to provide both severance pay and pension funds. This study will examine the impact of employee benefits liabilities on tax avoidance as a basis for regulatory considerations in making the derivative rules of UU Cipta Kerja.

With all the factors above, this research is expected to provide an explanation of the impact of employee benefits liabilities on tax avoidance. Employee benefits liabilities are part of company liabilities that can be used as deferred tax assets. Second, companies that have sales growth will get higher revenues and consequently increase the tax expense. Therefore, the possibility of a manager's encouragement to reduce tax expense with tax management in an effort to achieve the profit target that has been determined, may increase. Third, capital intensity is a representation of the amount that a company invests in fixed assets. Higher value of fixed assets can indicate higher depreciation expense which can be used to obtain lower taxes as a result of differences in accounting and taxation regulations (Noor et al., 2015). Fourth, tax avoidance can be done by earnings management. An increasing profit gives consequences of increasing tax expense, but earnings management could allow a company to earn high profits with a low tax expense. The proxy for earnings management in this study using Kothari Model to complete Jones Model (1991) by adding return on assets (ROA) as a performance control to reduce misspecifications. In addition, the reason Kothari model is used in this study because the measurement of discretionary accruals using the Kothari model is still not widely used in Indonesia.

\section{Literature Review}

\subsection{Agency Theory}

Agency theory describes the use of accounting to reduce agency costs. Agency relationship is a contract between the principal and the agent who is given the responsibility to handle the work on behalf of the principal (Jensen \& Meckling, 1976). This theory was triggered for the first time by Alchian and Demsetz (1972). The agent has received a delegation to make a decision from the principal. The agency problem arises from this theory because the manager seems to maximize the ownership of shareholders as principal, but they actually didn't. 
Firstly, this theory stated that there is a motivation for managers to choose accounting policies. Managers tend to reduce profits because of the debt hypothesis. This hypothesis says that the greater the debt to equity ratio of the entity, the greater manager will choose accounting policies that are able to shift profits from future to present (Watts $\&$ Zimmerman, 1978). Hence, this factor is measured by earning management. Second, bonus plan hypothesis is motivation of managers in choosing accounting policies because of the bonuses given (Miftah \& Murwaningsari 2018). Last, political cost hypothesis is prediction that managers have an opportunity to reduce profit reports and reduce their ability to bear political costs such as taxes (Godfrey et al., 2010). Furthermore, managers tend to minimize tax with tax management to produce maximal profit.

\subsection{Income Taxes and Tax Avoidance}

Law of the Republic of Indonesia number 36 of 2008 concerning fourth amendment of law number 7 of 1983 known as income tax law. Income definition based on Income Tax Law is "any increase in economic capacity received by or accrued by a taxpayer from Indonesia as well as from offshore, which may be utilized for consumption or increasing the taxpayer's wealth, in whatever name and form". In article 9 of Income Tax Law shows that not all expenses to calculate commercial profit are allowed to be deductible for tax purposes. Expenses that are deductible for income tax purposes are referred to as fiscal expenses. This cost is the cause that taxable income is different from accounting or commercial profit which causes book-tax differences. This can be used as tax avoidance by taxpayers to reduce their income tax.

Tax Avoidance is used by taxpayers (companies) to minimize the corporate tax burden (Ningrum et al., 2019; Lietz, 2013) describes the differences in tax avoidance, tax aggressiveness, tax sheltering, and tax evasion. Basically, some studies do not differentiate tax avoidance and tax aggressiveness. Those four mentions are basically part of tax avoidance. Lietz (2013) also categorizes Hanlon \& Heitzman (2010) measurement into the four designations of tax avoidance. This research is consistent with Lietz (2013) who grouped the four mentions as part of tax avoidance with the measurements suggested in his research. Hanlon \& Heitzman (2010) interpret tax avoidance as an action to minimize the expense of profit before tax. In this study, the definition of tax avoidance is consistent with the Lanis \& Richardson (2012) that define tax avoidance as tax planning activities in order to reduce taxable profit compared to accounting profit with an intention to pay minimum tax expense. Hence, this research uses tax avoidance from previous results to measure this variable.

\subsection{Employee Benefits Liabilities, Sales Growth, Capital Intensity, and Earnings management}

Employee benefits according to PSAK 24 is remuneration received by workers for the services they perform. Employee benefits liabilities arise from employee benefits which consist of short-term employee benefits liability, post-employment benefits liability, other long-term employee benefit liability, and termination severance liability. Frank (2002) provides evidence that pension plan is a capital structure option. A pension is a part of employee benefits liability that is paid after the employee has passed the retirement age. 
Tepper (1981) predicted that the company integrates worker benefit plans to reduce overall taxes. Post employment benefits are categorized by Laux (2013) as deferred tax assets that have been recognized in accounting but are not yet recognized in tax. Laux (2013); Sari \& Zulaikha (2015), prove that there is a relationship between deferred tax assets and deferred tax liabilities with future tax expenses. Swingly \& Sukartha (2015); Natalya (2018); Aprianto \& Dwimulyani (2019); Dinar et al., (2020), found negative effect leverage on tax avoidance. Nurhandono \& Firmansyah (2017) states that there is positive effect leverage on tax avoidance.

Sales growth can reflect sales between years. Sales growth can either increase or decrease. Sales growth is measured by the difference between current and previous year's sales divided by last year's sales (Kim \& Im, 2016). Increasing sales growth indicates an increase of the company's operating capacity (Budiman \& Setiyono, 2012). Therefore, the greater sales growth indicates the greater management to avoid taxes. In addition, sales growth also indicates increasing risk of bad debts. Bad debts in taxation can be used as a deduction cost to calculate taxable income but cannot be immediately recognized as a deduction expense because they need to meet several tax requirements. Swingly \& Sukartha (2015); Aprianto \& Dwimulyani (2019), found that there is no effect of sales growth on tax avoidance. Hidayat (2018) proves that there is a negative effect on sales growth on tax avoidance. Different from Nugraha \& Mulyani (2019) that found sales growth has a positive effect on tax avoidance.

Mulyani et al., (2014) stated that capital intensity shows capital owned by the company to earn income. Cai \& Liu (2009) argues that the depreciation method can be reduced before tax. Stickney \& McGee (1982) proves both net and gross fixed assets have an effect on tax avoidance. The higher of investment in depreciable assets, the higher tax savings means the lower effective tax rate. Stickney \& McGee (1982) found that a company who has low ETR has a high capital intensity. Dunbar et al., (2010) argue that capital intensity relates to overall tax planning opportunity. Natalya (2018); Nugraha \& Mulyani (2019) prove that capital intensity has a positive effect on tax avoidance.

According to Martani (2012), profit is income that is obtained if the financial value of net assets at the end of the period is greater than the beginning of the period. According to Jones (1991), earnings management is a manager's action to get benefits for each entity. Earnings management is performed to change the value of financial statements by using accounting valuation and arranging transactions in some way. It may give an effect that can distort users of financial statements (Healy \& Wahlen, 1999). Thus, it can be concluded that earnings management is the act of managers choosing a reporting method which results in inaccuracy in reflecting the economic reliability of the company. Frank et al., (2009) proves that there is a positive influence between tax aggressiveness on financial reporting. Fernandes et al., (2017) stated that companies that have aggressive financial reports tend to have aggressive tax reporting as well. Nurhandono \& Firmansyah (2017) stated that there is a positive effect of leverage on tax avoidance. 


\subsection{Hypotheses and Research Question}

These study areas of investigation are intended to assess the level of tax avoidance of the manufacturing industry in Indonesia and the role of employee benefit liabilities, sales growth, capital intensity, and earnings management in effecting this. To analyse this, it expects some relationship among these factors as the following hypotheses:

H1: Employee benefits liabilities has a positive effect on tax avoidance

$\mathrm{H} 2$ : Sales growth has a positive effect on tax avoidance

H3: Capital intensity has a positive effect on tax avoidance

H4: Earnings management has a positive effect on tax avoidance

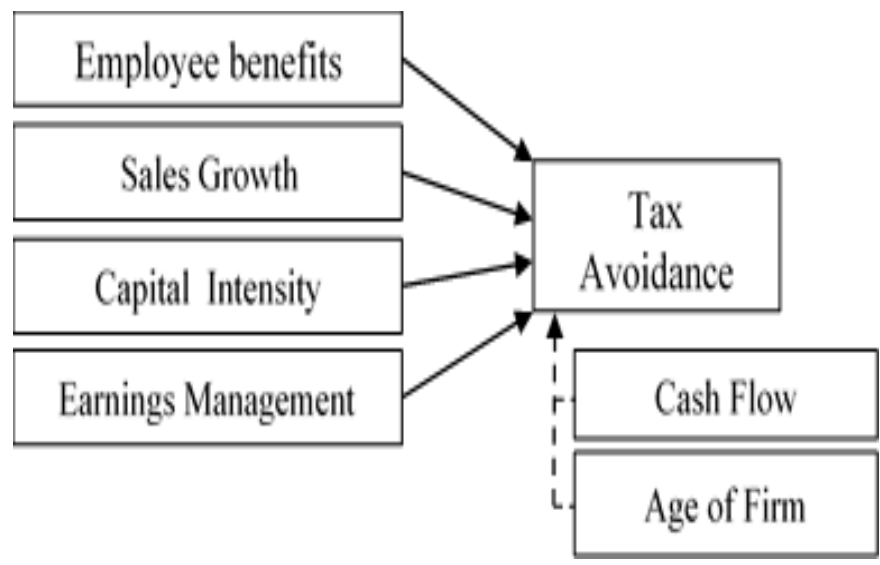

Figure 1. Conceptual Framework

\section{Research Method}

\subsection{Research Subjek}

The samples used are manufacturing companies listed on the Indonesia Stock Exchange from 2016-2019. The proxy used is ETR as an implication of tax avoidance.

\subsection{Metode Pengumpulan Data}

This research uses a quantitative method. Then, this study uses panel data. With the help of statistics, multiple linear regression methods were performed to do panel data analysis. The sample selection use purposive sampling based on the following criteria: (1) The company publishes audited financial statements as of December 31 from 2016-2019; (2) The company did not have losses before tax or after tax during 2016-2019; (3) The company has complete information as needed in the research. Data processing for descriptive statistical tests and inferential statistics using STATA 14.2. The regression equation of this main model is as follows:

$$
\begin{aligned}
\text { ETRi,t }: & \alpha 0+\beta 1 \text { LIKi,t }+\beta 2 \text { SALESi,t }+\beta 3 \text { CAPINTi,t }+\beta 4 E M i, t+\beta 5 C F O i, t+ \\
& \beta 6 \text { AGEi,t }+\varepsilon i, t
\end{aligned}
$$

where:

ETR : Effective Tax Rate

LIK : Employee Benefit Liabilities

SALES : Sales Growth CAPINT = Property, Plant, Equipment 


$\begin{array}{ll}\text { EM } & : \text { Earnings Management } \\ \text { CFO } & : \text { Cash Flow Operation } \\ \text { AGE } & : \text { Age of Firm } \\ \alpha & : \text { Konstanta } \\ \beta & : \text { Coefficient } \\ \varepsilon & : \text { Error term }\end{array}$

Kothari Model is used to measure earnings management. Kothari et al., (2005) argued that this model can reduce specification errors in detecting earnings management with the following formula:

$$
T A C C_{i, t}=\alpha_{0}+\alpha_{1} \Delta R E V_{i, t}+\alpha_{2} P P E_{i, t}+R O A_{i, t}-1+\varepsilon i, t
$$

To calculate error value or residual value, cross-sectional regression is performed for every year from 2016 to 2019. Before regressing, TACC value must be defined:

$$
\mathrm{TACC}_{i, t}=N I_{i, t}-\mathrm{CFO}_{i, t}
$$

where:

TACC $_{i, t}$ : total accruals of company $i$ in year $t$ the difference in revenue of company $i$ in year $t$ less operating cash flow $i$ in year $t$

$\mathrm{NI}_{\mathrm{i}, \mathrm{t}} \quad$ : net income company i year $\mathrm{t}$

$\mathrm{CFO}_{\mathrm{i}, \mathrm{t}}$ : operating cash flow company $\mathrm{i}$ year $\mathrm{t}$

$\triangle \mathrm{REV}_{\mathrm{i}, \mathrm{t}}$ : the difference between changes in sales of company $\mathrm{i}$ in year $\mathrm{t}$ with $\mathrm{t}-1$ with changes in receivables of company $i$ in year $t$ with $t-1$

$\mathrm{PPE}_{\mathrm{i}, \mathrm{t}} \quad$ : the gross value of company $\mathrm{i}$ fixed assets in year $\mathrm{t}$

$\mathrm{ROA}_{\mathrm{i}, \mathrm{t}}$ : return on assets of company $\mathrm{i}$ in year $\mathrm{t}-1$

eit $\quad$ : discretionary accruals for company $\mathrm{i}$ in year $\mathrm{t}$

This research calculates the amount of tax avoidance using the Effective Tax Rate (ETR). ETR is a tool most often used to measure how much companies can do tax avoidance (Lanis \& Richardson, 2012). This measurement is also used by Natalya (2018) $\&$ Hidayat (2018). Current ETR is measured by current tax expense consolidation divided profit before tax:

ETR $=($ Beban Pajak Kini) $/$ (Laba Sebelum Pajak)

ETR is a negative proxy. Tax avoidance can be seen through the small ETR value (Lanis \& Richardson, 2012). A small ETR value means that tax avoidance is getting higher and if the ETR value is high it means that tax avoidance is getting lower.

\section{Result And Discussion}

\subsection{Descriptive Statistics}

The result of the purposive sampling method used to select samples shows that from 193 manufacturing companies listed on the IDX in November 2020, 78 companies were selected with 4 years research time so that the obtained final sample used is 312 firm-year observations. 
Tabel 1

Research Sample

\begin{tabular}{|l|c|}
\hline Manufacturing companies listed on the IDX as of November 30,2020 & 193 \\
\hline $\begin{array}{l}\text { Elimination: } \\
\text { - The company publishes financial reports as of December 31 } \\
\text { - The company incurred a loss before tax and after tax }\end{array}$ & $(50)$ \\
- The company does not fulfill the required data & $(59)$ \\
\hline Total number of samples & $(6)$ \\
\hline Research Period (2016-2019) & 78 \\
\hline Total observation & 4 \\
\hline
\end{tabular}

Table 2 presents the descriptive statistics of the study. To make a sharp interpretation, outlier data can be treated by winsorize technique. Observation data using winsor command at $10 \%$ of the lower and upper limit.

Tabel 1

\section{Research Sample}

\begin{tabular}{|l|c|c|c|c|c|}
\hline \multicolumn{1}{|l}{ Variabel } & N & \multicolumn{1}{c}{ Mean } & \multicolumn{1}{c|}{ Std. Dev. } & Min & Max \\
\hline ETR & 312 & 0,2566469 & 0,0684841 & 0,1307515 & 0,406431 \\
\hline LIK & 312 & 0,0353478 & 0,0245476 & 0,007716 & 0,0855704 \\
\hline SALES & 312 & 0,0835725 & 0,1100211 & $-0,1345297$ & 0,317062 \\
\hline CAPINT & 312 & 0,3757833 & 0,1539876 & 0,1401811 & 0,620199 \\
\hline EM & 312 & $-0,0043535$ & 0,0512216 & $-0,1136511$ & 0,0855289 \\
\hline CFO & 312 & 0,0823075 & 0,0675841 & $-0,0269447$ & 0,2152684 \\
\hline AGE & 312 & 20,07692 & 9,023398 & 3 & 30 \\
\hline
\end{tabular}

The average of ETR is 0.2566469 or $25.66 \%$. This is consistent with the tax rate determined by the Directorate General of Taxation that the tax rate for companies is $25 \%$ which means that on average companies comply with tax regulations. Mean of LIK variable is 0,0353478 . This implies that, on average, the company has Rp 0.0353478 for employee benefits liabilities for every Rp1 of its assets. The average employee benefit liability variable is consistent at $3 \%$ for each year. This indicates that in general the company is not aggressive in reducing employee benefit liabilities in an extreme way such as reducing employees with mass layoffs caused by bankruptcy or the economic downturn.

The average of SALES is 0,083572 indicates that companies sample get an increasing sales growth from the previous year. SALES analysis for every year, on average, companies have the highest sales increase in 2018, but as a result, in the following year, 2019 has the smallest sales growth ratio. This is because of the increasing sales in 2018 was the highest so that the increase in sales for the following year, namely in 2019, has a smaller value. Besides, the highest sales increase in 2018 was presumed from a surge in domestic demand and job growth. 
Mean CAPINT is 0.3757833 means that the company's capital invested in fixed assets is 37\% of its total assets. Mean CAPINT are decreasing in 2017 and 2018 then increased in 2019. It shows that companies in general are still using fixed assets owned from 2016 or the previous year to 2018 and starting to buy fixed assets again in 2019, as a result of depreciation which can reduce the efficiency of fixed assets in operating business. Through a press release from the Ministry of Industry, it is known that there was a surge in domestic demand in 2018. Another cause of the increase in fixed assets is the highest sales growth in 2018 makes the company have the ability to add fixed assets.

The average of earnings management is negative. This shows that managers are doing income decreasing. It is suspected that the company management might tell an implicit message so that regulators can make regulations that are appropriate and expected by company management, such as tax relief. CFO has a mean value of 0.0823075 . Both the highest and the lowest value are owned by the consumption sector. AGE has a mean value of 20,07692. From the descriptive data it is known that there are sample companies that have been listed on the Indonesia Stock Exchange since 1989 (2019-30).

\subsection{Pre-Regression Test Results}

The hypothesis in this study is tested using panel data regression. This study performs Chow test, Langrange Multiplier test, and Hausman test to know the best model. Prob> chi2 on the Hausman test is 0.8247 means that the best model for this study is random effect. The Shapiro-Wilk test shows the value of Prob>z of 0.01362 means that residual is not normally distributed. Gujarati \& Porter (2009) states that with a large sample size, it's very difficult to obtain normal data distribution and panel data with a number of observations of more than one hundred can be said to have met the normality of the data so that the assumption of normality can be ignored.

Correlation test results from this research are:

1. Multicollinearity test. Correlation Matrix Test shows that there is no value more than 0.8 for all correlations between independent variables. So, the conclusion is there are no multicollinearity problems that arise in each of the variables used. This is supported by the results of the Variance Inflation Factor (VIF) test that the VIF number for each independent variable is lower than 10 .

2. Autocorrelation test. The result of the Wooldridge Test shows that the value of Prob> $\mathrm{F}$ is 0.0934 which means that it is greater than the level of significance and the regression model has no autocorrelation problem.

3. Heteroscedasticity test. The result of the Modified Wald Test shows that Prob $>$ chi 2 is 0,0000 which means that there is a heteroscedasticity problem. However, heteroscedasticity test does not need to be done because the random effect model testing has used the Generalized Least Square (GLS) (Maulana \& Muchtar, 2018).

\subsection{Hypothesis Test}

The value of the $\mathrm{R} 2$ coefficient in this study is $12.36 \%$ which means that independent and control variables can explain $12.36 \%$ of the dependent variable. While the remaining $87.64 \%$ of the variation in the dependent variable is explained by other variables not examined in this research model. The low value of the R2 coefficient is not only because 
the independent variable cannot explain the ETR dependent variable, it is also thought to be due to the wide scope of the ETR measurement used. This happened in several studies that found a low R2 coefficient to explain ETR as the dependent variable. The research is Aprianto \& Dwimulyani (2019) of 5.1\%, Dinar et al. (2020) at 14.5\%, Hidayat (2018) $29.6 \%$, Natalya (2018) at 3.59\%, and Nugraha \& Mulyani (2019) at $13.5 \%$.

Prob value $>$ chi2 of 0.0003 means that the independent and control variables are able to have a significant effect on the dependent variable.

\section{Tabel 3}

Research Sample

\begin{tabular}{|l|cccc|c|}
\multicolumn{1}{l}{ ETR } & Coef. & $\mathbf{P}>\mathbf{z} \mid$ & \multicolumn{2}{c}{ [95\% Conf. Interval] } & Sig. Level \\
\hline LIK & 0,5110011 & 0,013 & 0,0622847 & 0,9597175 & $5 \%$ \\
SALES & $-0,0698183$ & 0,004 & $-0,1212703$ & $-0,0183662$ & $5 \%$ \\
CAPINT & $-0,0665740$ & 0,024 & $-0,1322138$ & $-0,0009342$ & $5 \%$ \\
EM & $-0,1585822$ & 0,017 & $-0,3052359$ & $-0,0119284$ & $5 \%$ \\
CFO & $-0,1438059$ & 0,019 & $-0,2790179$ & $-0,0085938$ & $5 \%$ \\
AGE & $-0,0002976$ & 0,329 & $-0,0016123$ & 0,0010170 & $5 \%$ \\
\hline
\end{tabular}

To determine the magnitude of the individual influence of each independent variable on the dependent variable, we perform z statistical test. In this study, ETR is a negative proxy. $\mathrm{Z}$ probability value of employee benefit liability (LIK) is 0.013 . Therefore, the employee benefits liability variable has a significant effect on ETR. Table 3 shows that LIK has a significant positive effect on ETR. Thus, it can be concluded that LIK has a significant negative effect on tax avoidance. PMK RI Number 169/ PMK.010/2015 appropriates not to categorize employee benefit liabilities as borrowing costs. In reducing income tax, employee benefit liability differs from leverage. Leverage reduces income tax by calculating interest as an expense while employee benefit liabilities reduce income tax when the transaction has occurred.

The $\mathrm{z}$ probability value of sales growth (SALES) variable is 0.004 . Table 3 shows that SALES has a negative coefficient value on ETR. Thus, it can be concluded that SALES has a significant positive effect on tax avoidance. High sales growth indicates high ability in tax management. In general, profit after tax can be used as a success measurement of management in operating the company. Consistent with the agency theory that there are differences interests of agents and principals. Management will strive to increase sales and minimize tax expense to achieve the targets so they can get incentives from it. Sales growth also indicates an increased risk of bad debts that could be charged as an expense.

$\mathrm{Z}$ probability value of capital intensity (CAPINT) sebesar 0,024 . Table 3 shows that CAPINT has a coefficient value of -0.0665740 . CAPINT has a significant positive effect on tax avoidance. Useful life, depreciation method, and residual value lead to differences in the amount of depreciation in taxable income. Asset revaluation can be used for tax management by analyzing cost and benefit between tax expense on revaluation and the 
fiscal depreciation expense during the useful life as a deduction from taxable income. In addition, lease payments for fixed assets can be used as a deduction for tax income and minimize tax expense.

Earnings management (EM) has 0.017 for z probability value. Differences between accounting standards and tax law allows companies to use loopholes to avoid taxes can be a cause of this. In addition, the manufacturing sector has certain characteristics that make earnings management can be done by managers. Total of observations based on the recommendation of the Kothari Model is assumed to be in accordance with the measurement of "normal" earnings management which supports the effect of earnings management on tax avoidance. The $\mathrm{z}$ probability value of operating cash flow variable (CFO) as a control variable is 0.019 . Table 3 shows that CFO has a significant negative effect on ETR so that CFO has a significant positive effect on tax avoidance. Different from z probability value of the company age variable (AGE) as a control variable is 0.329 . This value is higher than the 5\% significance level. Therefore, the company age variable has no effect on ETR.

\section{Conclusion}

This research uses the manufacturing sector from 2016 to 2019 which is listed on the Indonesia Stock Exchange. The number of samples selected is 312 observational data. Based on the results of the random effect model regression, it is found that: employee benefits liabilities have a negative effect on tax avoidance, while sales growth, capital intensity, and earnings management have a positive effect on tax avoidance. Positive effect of capital intensity on tax avoidance can be used as an indicator by the Directorate General of Taxation for improving supervision of corporate taxpayers who have high fixed assets. Directorate General of Taxation can make a limitation for the total value of accrual discretion as taxpayer non-compliance. For further research, our recommendation is to use other proxies in measuring tax avoidance with the measurements summarized by Hanlon \& Heitzman (2010). Another recommendation is expanding the research sector and research period to obtain generalizable results.

The results of this research can be used as a consideration for regulators in drafting a Government Regulation as a derivative rule of UU Cipta Kerja. Regulators need to evaluate the effectiveness of PMK RI Number 169/PMK.010/2015 as an anti-tax avoidance policy. This study also has limitations. The limitation in this research may occur inaccurate ability to the result of other research, which are: First, this research only uses tax payers which are listed on the Indonesia Stock Exchange. Hence, it does not represent all kinds of tax payers. Second, ETR only measure legal tax avoidance, it can not describe illegal tax avoidance or tax evasion. Third, ETR measurement uses consolidated current tax expense because the research does not get the data that is owned by the Directorate General of Taxes. The use of data from the DGT will make research data more valid in terms of the tax authorities and provide practical benefits in mapping taxpayers who have indications of tax avoidance. 
This research recommend several points to do in other research, which are: first, The subject of the research widely expands to other companies, for example used companies that are not listed or individual taxpayers. Second, using other variables that are not included in financial reports. Third, the Directorate General of Taxes can use taxpayers data to measure agretivity of tax avoidances.

\section{References}

Alchian, A. A. \& H. Demsetz. (1972), Production, information costs, and economic organization, The American economic review, Vol. 62 No. 5, pp. 777-795.

Aprianto, M., \& Dwimulyani, S. (2019). Pengaruh sales growth dan leverage terhadap tax avoidance dengan kepemilikan institusional sebagai variabel moderasi. Prosiding Seminar Nasional, Vol. 2, pp. 1-10.

Aprilianti, A. A, PENGARUH KESADARAN WAJIB PAJAK, SOSIALISASI PERPAJAKAN, INSENTIF PAJAK, DAN SISTEM E-SAMSAT TERHADAP KEPATUHAN WAJIB PAJAK KENDARAAN BERMOTORDI MASA PANDEMI COVID-19, Assets: Jurnal Ekonomi, Manajemen dan Akuntansi, Vol. 1 No. 1 , pp. $1-20$

Budiman, J., \& Setiyono, S. (2012), Pengaruh karakter eksekutif terhadap penghindaran pajak (Tax avoidance), Simposium Nasional Akuntansi XV, Vol. 6. http://etd.repository.ugm.ac.id/home/detail_pencarian/54398

Cai, H., \& Liu, Q. (2009), Competition and corporate tax avoidance: Evidence from Chinese industrial firms, In Economic Journal, Vol. 119 No. 537. Doi: 10.1111/j.1468-0297.2009.02217.x

Dinar, M., Yuesti, A., \& Dewi, N. P. S. (2020), Pengaruh profitabilitas, likuiditas dan leverage terhadap agresivitas pajak pada perusahaan manufaktur yang terdaftar di BEI, Jurnal Kharisma, Vol. 2 No. 1, pp. 66-73.

Dunbar, A., Higgins, D. M., Phillips, J. D., \& Plesko, G. A. (2010), What do measures of tax aggressiveness measure?, National Tax Association Proceedings, 18-26. https://www.ntanet.org/wp-content/uploads/proceedings/2010/003-dunbar-whatdo-measures-2010-nta-proceedings.pdf

Dyreng, S. D., Hanlon, M., \& Maydew, E. L. (2014), Tax avoidance corporate, American Accounting Association, Vol. 83 No. 1, pp. 61-82.

Erickson, M., Hanlon, M., \& Maydew, E. L. (2004), How much will firms pay for earnings. The Accounting Review, Vol. 79 No. 2, pp. 387-408.

Fernandes, A., Cerqueira, A., \& Brandão, E. (2017), Tax and financial reporting aggressiveness: Evidence from Europe, Journal of Public Economics, pp. 1-47. doi:10.2308/accr.2009.84.2.467.

Frank, M. M. (2002), The impact of taxes on corporate defined benefit plan asset allocation. Journal of Accounting Research, Vol. 40 No. 4, pp. 1163-1190.

Frank, M. M., Lynch, L. J., \& Rego, S. O. (2009), Tax reporting aggressiveness and its relation to financial reporting, Accounting Review, Vol. 84 No. 2, pp. 467-496. https://www.jstor.org/stable/27802660 
Godfrey, J., Hodgson, A., Tarca, A., Hamilton, J., \& Holmes, S. (2010), Accounting Theory (7th ed.), Milton, Qld., Wiley \& Sons.

Gujarati, D. N., \& Porter, D. C. (2009), Basic econometrics (Fifth Edit), Salemba Empat, Jakarta.

Hanlon, M., \& Heitzman, S. (2010), A review of tax research, Journal of Accounting and Economics, Vol. 50 No. (2-3), pp. 127-178.

Healy, P. M., \& Wahlen, J. M. (1999). A review of the earnings management literature and its implications for standard setting. Accounting Horizons, 13(4), 365-383. https://doi.org/10.2308/acch.1999.13.4.365

Hidayat, W. W. (2018). Pengaruh profitabilitas, leverage dan pertumbuhan penjualan terhadap penghindaran pajak. Jurnal Riset Manajemen Dan Bisnis (JRMB) Fakultas Ekonomi UNIAT, Vol. 3 No. 1, pp. 19-26.

Jensen, M. C., \& Meckling, W. H. (1976), Racial diversity and its asymmetry within and across hierarchical levels: The effects on financial performance, Human Relations, Vol. 72 No. 10, pp. 1671-1696.

Jones, J. J. (1991). Earnings management during import relief investigations. Jornal of Accounting Research, $29(2)$

193-228. https://doi.org/https://doi.org/10.2307/2491047

Kementerian Perindustrian. 2020. Laporan Kinerja Kementerian Perindustrian 20152019: Transformasi Manufaktur Menuju Industri Maju.

Kim, J. H., \& Im, C. C. (2016), Corporate tax avoidance in SME: The effect of listing, International Journal of $U$ - and e-Service, Science and Technology, Vol. 9 No. 6, pp. 283-294.

Kothari, S. P., Leone, A. J., \& Wasley, C. E. (2005), Performance matched discretionary accrual measures, Journal of Accounting and Economics, Vol. 39 No. 1, pp. 163197.

Lanis, R., \& Richardson, G. (2012), Corporate social responsibility and tax aggressiveness: An empirical analysis, Journal of Accounting and Public Policy, Vol. 31 No. 1, pp. 86-108.

Laux, R. C. (2013), The association between deferred tax assets and liabilities and future tax payments, Journal of International Accounting Research, Vol. 90 No. 4, pp. 1395-1435.

Lietz, G. (2013). Tax avoidance vs tax aggressiveness: Unifying conceptual framework. Working Paper. https://doi.org/10.2139/ssrn.2363828

Marfiana, A (2020), Overview Of Added Value-Added Taxes In Connection With Covid19 Virus Plague: Vat Facilities Or Tax Incentives?, Jurnal Manajemen STIE Muhammadiyah Palopo, Vol. 6 No. 1, pp. 17-24.

Martani, D. (2012), Akuntansi keuangan menengah berbasis PSAK, Salemba Empat: Jakarta.

Maulana, T., \& Muchtar, P. P. S. (2018), Modul metode penelitian akuntansi. Politeknik Keuangan Negara STAN, https://www.google.com/url?sa=t\&rct=j\&q=\&esrc=s $\&$ source=web\&cd=\&cad=rja\&uact=8\&ved=2ahUKEwix47jlxbLuAhVVJHIKH 
WzlAS0QFjAAegQIAxAC\&url=https\%3A\%2F\%2Fstaff.blog.ui.ac.id\%2Fmarta ni\%2Ffiles\%2F2018\%2F09\%2FModul-STAN-

1.docx\&usg=AOvVaw2udouR5DbxRjUpTw6etpD5

Miftah, D. \& E. Murwaningsari (2018), Bonus plan and income smoothing on the selection of accounting policy and corporate governance determination manufacturing companies listed on the Indonesian Stock Exchange evidence, Journal of Resources Development and Management: An international peerreviewed journal, Vol. 41.

Mulyani, S. (2014), Pengaruh Karakteristik Perusahaan, Koneksi Politik Dan Reformasi Perpajakan Terhadap Penghindaran Pajak (Studi Pada Perusahaan Manufaktur yang Terdaftar di Bursa Efek Tahun 2008-2012), Jurnal Mahasiswa Perpajakan, Vol. 2 No. 1, pp. 1-9.

Natalya, D. (2018). Pengaruh capital intensity, leverage dan profitabilitas terhadap tax agresivitas dengan kinerja pasar sebagai variabel moderating. Media Akuntansi Perpajakan, 3(1), 37-55. http://journal.uta45jakarta.ac.id/index.php/MAP

Ningrum, E. M., Samrotun, Y. C., \& Fajri, R.N. (2019), Tax Avoidance Ditinjau Dari Corporate Governance Pada Perusahaan Property Dan Real Estate, Jurnal Manajemen STIE Muhammadiyah Palopo, Vol. 5 No. 2, pp. 100-115.

Noor, N. F. M., Sanusia, Z. M., Heang, L. T., Iskandar, T. M., \& Isa, Y. M. (2015), Fraud motives and opportunities factors on earnings manipulations, Procedia Economics and Finance, Vol. 28, pp. 126-135.

Nugraha, M. I., \& Mulyani, S. D. (2019), Peran Leverage Sebagai Pemediasi Pengaruh Karakter Eksekutif, Kompensasi Eksekutif, Capital Intensity, dan Sales Growth Terhadap Tax Avoidance, Jurnal Akuntansi Trisakti, Vol. 6 No. 2, 301-324.

Nurhandono, F., \& Firmansyah, A. (2017), Lindung Nilai, Financial Leverage, Manajemen Laba dan Agresivitas Pajak, Jurnal Media Riset Akuntansi, Auditing \& Informasi, Vol. 17 No. 1, pp. 31-52.

Oktariani, F., \& Lembut, P. I. (2019), Tax Avoidance Sebagai Latar Belakang Dalam Memanfaatkan Tax Deductible Expense (Studi Pada Perusahaan Manufaktur yang Terdaftar di BEI). InFestasi, Vol. 14 No. 2, pp. 154-168.

Republik Indonesia. (2020), Undang-Undang Republik Indonesia Nomor 11 Tahun 2020 tentang Cipta Kerja, Sekretariat Negara, Jakarta

Republik Indonesia. (2015), Peraturan Menteri Keuangan Republik Indonesia Nomor 169/PMK.010/2015 tentang Penentuan Besarnya Perbandingan Antara Utang dan Modal Perusahaan untuk Keperluan Penghitungan Pajak Penghasilan, Sekretariat Negara, Jakarta

Samuel Pablo. 2019. Kemenkeu, OJK \& BEI Kompak Sanksi Garuda karena Lapkeu 2018 https://www.cnbcindonesia.com/market/20190629120802-1781567/kemenkeu-ojk-bei-kompak-sanksi-garuda-karena-lapkeu-2018. Diakses tanggal 10 November 2020

Sari, R. K., \& Zulaikha, Z. (2015), Pengaruh Komponen Aset dan Kewajiban Pajak Tangguhan Terhadap Beban Pajak Kini Masa Depan. Diponegoro Journal of Accounting, Vol. 4, pp. 1-13. 
Shayan-Nia, M., Sinnadurai, P., Mohd-Sanusi, Z., \& Hermawan, A. N. A. (2017), How efficient ownership structure monitors income manipulation? Evidence of real earnings management among Malaysian firms, Research in International Business and Finance, Vol. 41, pp. 54-66.

Siti Nur Azzura. 2019. Fakta-Fakta Kesalahan Laporan Keuangan Garuda Indonesia Hingga Dikenakan Sanksi. https://www.merdeka.com/uang/fakta-faktakesalahan-laporan-keuangan-garuda-indonesia-hingga-dikenakan-sanksi.html. Diakses tanggal 10 November 2020

Stickney, C. P., \& McGee, V. E. (1982), Effective corporate tax rates the effect of size, capital intensity, leverage, and other factors, Journal of Accounting and Public Policy, Vol. 1 No. 2, pp. 125-152.

Swingly, C., \& Sukartha, I. M. (2015), Pengaruh karakter eksekutif, komite audit, ukuran perusahaan, leverage, dan sales growth pada tax avoidance, E-Jurnal Akuntansi Universitas Udayana, Vol. 1, pp. 47-62.

Tepper, I. (1981). Taxation and corporate pension policy. The Journal of Finance, Vol. 36 No. 1, p. 1.

van Dorp, L., Acman, M., Richard, D., Shaw, L. P., Ford, C. E., Ormond, L., ... \& Balloux, F. (2020), Emergence of genomic diversity and recurrent mutations in SARSCoV-2, Infection, Genetics and Evolution, Vol. 83, p. 104351.

Victoria, A., O. 2020, Penerimaan Pajak Berpotensi Hilang Rp 80 Triliun akibat Omnibus Law https://katadata.co.id/agustiyanti/finansial/5e9a495ccb23f/pener maan-pajak-berpotensi-hilang-rp-80-triliun-akibat-omnibus-law. Diakses tanggal 10 November 2020

Watts, R. L., \& Zimmerman, J. L. (1978), Towards a positive theory of the determination of accounting standards towards a positive theory of the determination of accounting. The Accounting Review THE ACCOUNTING REVIEW, Vol. 53 No. 1, pp. 112-134.

Wind, B., Dewilde, C., \& Doling, J. (2020), Secondary property ownership in Europe: Contributing to asset-based welfare strategies and the 'really big trade-off, International Journal of Housing Policy, Vol. 20 No. 1, pp. 25-52. 